\title{
Production of biosurfactant by Nocardia otitidiscaviarum and its role in biodegradation of crude oil
}

\author{
${ }^{1 * T . ~ K . ~ V y a s ; ~}{ }^{2}$ B. P. Dave \\ ${ }^{1}$ P D Patel Institute of Applied Sciences, Charotar University of Science and Technology, Changa, Gujarat, India \\ ${ }^{2}$ Department of Life Sciences, Bhavnagar University, Bhavnagar, Gujarat, India \\ Received 25 June 2010; revised 11 August 2010; accepted 12 February 2011; available online 1 March 2011
}

\begin{abstract}
Nocardia otitidiscaviarum microbial type cultural collection 6471 isolated from oil contaminated Alang India seawater was examined for production of surface active compound. Isolate shows halos and $\alpha$-heamolysis on cetyl trimethyl ammonium bromide and blood agar respectively indicating the production of biosurfactant. Biosurfactant was extracted by precipitation and was partially purified. Partially purified product was characterized by thin layer chromatography and Infra-red spectroscopy and was identified as glycolipid. Sugar present in glycolipid was rhamnose and hence, biosurfactant was quantified as rhamnose equivalent. Role of cell-surface hydrophobicity and emulsification activity in correlation with biosurfactant production was examined. Correlation between biosurfactant production, growth and crude oil degradation was also examined and showed positive correlation at significant level 0.001 and 0.01 respectively. Thus, this is a first report on a marine strain of Nocardia otitidiscaviarum microbial type culture collection 6471 , which can be a potential candidate for restoration of oil contaminated marine environment.
\end{abstract}

Keywords: Bioavailability; Bioremediation; Cell surface hydrophobicity; Emulsification; Glycolipids

\section{INTRODUCTION}

A major limiting factor in hydrocarbon degradation is the lack of bioavailability of hydrocarbons due to poor solubility, leading to its accumulation with accompanying toxic and carcinogenic effects (Juang et al., 2009a; Juang et al., 2009b). In nature, a few smart organisms tackle the hydrocarbon uptake either by direct contact e.g., by producing surface active compounds or by attaching themselves to these compounds. Both of these mechanisms involve modulation of cellular physiology that leads either to secretion of surface active compounds into the medium or changes in cell surface properties like hydrophobicity or a combination of both (Prabhu and Phale, 2003; Adams et al., 2008; Kosamu and Obst, 2009). Surfactants being amphiphilic molecules consisting of hydrophilic and hydrophobic moiety find wide range of application in bioremediation as well as in various industries. The ability of biosurfactants to emulsify hydrocarbon-water mixtures has been very well

*Corresponding Author Email: vyastrupti@hotmail.com Tel./Fax: +9196 62030836 documented (Oberbremer et al., 1990; Francy et al., 1991; Zhang and Miller, 1992; Goyal et al.,2008). This property has been demonstrated to increase hydrocarbon degradation significantly, thus it is potentially useful for oil spill management (Atlas and Bartha, 1992; Banat 1993; Bonin et al., 1994; Husseien et al., 2009; Nagheeby and kolahdoozan, 2010). Haghighat et al. (2008) reported indigenous isolate from crude oil storage tank in Tehran Refinery, Tehran, Iran, Bacillus licheniformis and Bacillus subtitlis for MEOR which produce lipopetide biosurfactant.

Hydrocarbon degrading microbes also respond to hydrophobic compounds by changing cell surface properties, such as cell surface hydrophobicity (AlTahhan et al., 2000; Beal and Betts 2000). In a microbial culture, there are three pools of biosurfactant: an intracellular pool including membrane lipids, an extracellular pool including excreted polysaccharideprotein-lipid complex and an interposed cell surface pool located on the cell wall and capsule including lipid and lipid-polymer complex (Alexander, 1999). 
Biosurfactant from the cell surface pool may leads to changes in cell surface properties, by inserting amphiphilic molecules in their cell-surface, assuring efficient transport by attachment to hydrophobic substance i.e., by increasing cell-surface hydrophobicity.

Cells with higher hydrophobicity have better chance to adhere to oil droplets than cells with lower hydrophobicity. Thus, cells showing higher hydrophobicity may have better potential to degrade hydrocarbon. Beside its role in hydrocarbon uptake, cell surface hydrophobicity plays an important role in bacterial invasion and infection, cell adhesion, biofilm formation, etc. (Panagoda et al., 2001; Singleton et al., 2001).

The present study reports growth dependant production of extra cellular biosurfactant (BS) and its chemical characterization, how it brings about changing in cell surface hydrophobicity, emulsification activity and thereby its role in enhancing hydrocarbon degradation.

\section{MATERIALS AND METHODS}

\section{Organisms}

Nocardia otitidiscaviarum microbial type culture collection (MTCC) 6471 was isolated form crude oil contaminated sea water and sediments collected from Alang coast, Gujarat, India, known for its extensive ship-breaking yard activities. These activities release tones of oil into the marine environment, polluting the marine ecosystem and thus, threatening biological diversity. The isolates were maintained on Zobell Marine Agar and stored at $4^{\circ} \mathrm{C}$ until use (Zobell, 1946). As Nocardia otitidiscaviarum is an ear pathogen, due care was taken during and after experimentation.

\section{Plate assays for BS production}

Blue agar: Blue agar plate containing cetyl trimethyl ammonium bromide $(\mathrm{CTAB})(0.2 \mathrm{mg} / \mathrm{mL})$ and methylene blue $(5 \mu \mathrm{g} / \mathrm{mL})$ was used to detect extracellular glycolipid production (Siegmund and Wagner, 1991). Culture was streaked and incubated to observe the formation of dark blue halos around the colonies.

Blood agar: BS causes hemolysis of blood (Johnson and Boese-Marrazzo, 1980). Cells were streaked on blood agar plates (nutrient agar with $5 \%$ blood) and incubated at room temperature for 5-6 days to observe for the hemolysis of blood.
Chemical characterization and quantification of BS Partial purification of BS

Cells were inoculated in a medium (per liter $\left(\mathrm{NH}_{4}\right)_{2} \mathrm{SO}_{4} 1 \mathrm{~g}, \mathrm{~K}_{2} \mathrm{HPO}_{4} 1.5 \mathrm{~g}, \mathrm{KH}_{2} \mathrm{PO}_{4} 0.75 \mathrm{~g}$, Yeast extracts $1 \mathrm{~g}, \mathrm{MgSO}_{4} \cdot 7 \mathrm{H}_{2} \mathrm{O} 0.5 \mathrm{~g}$, Trace element solution $20 \mathrm{~mL}$; Trace element solution per litre contain $\mathrm{NaCl} 5 \mathrm{~g}, \mathrm{CaCl}_{2} \cdot 2 \mathrm{H}_{2} \mathrm{O} 0.5 \mathrm{~g}, \mathrm{MnSO}_{4} \cdot 5 \mathrm{H}_{2} \mathrm{O} 0.5$ $\mathrm{g}, \mathrm{FeSO}_{4} \cdot 7 \mathrm{H}_{2} \mathrm{O} 0.5 \mathrm{~g}$ ) as described by Cho et al. (1998) supplemented with $5 \mathrm{~g} / \mathrm{L}$ of crude oil. The flasks were incubated at optimum temperatures for growth and degradation i.e., $25^{\circ} \mathrm{C}$ on a rotary shaker at $150 \mathrm{rpm}$ for 7 days. Seven day old culture was centrifuged at 10,000 $\mathrm{rpm}$ for $15 \mathrm{~min}$. The cell pellet was removed and $\mathrm{pH}$ of the culture supernatant was lowered to 2.0 with $6 \mathrm{~N} \mathrm{HCl}$ and allowed to stand overnight at $4{ }^{\circ} \mathrm{C}$. Extraction was carried out twice with chloroform : methanol $(2: 1)$ and the BS was recovered from the solvent using rotary vacuum evaporator and dissolved in chloroform for further analyses.

\section{Chemical nature of biosurfactants}

The lipid components that determine the surfaceactive properties of the BS were detected by spotting the partially purified BS on silica gel $60\left(\mathrm{~F}_{254}\right.$ Merck, Germany) plates in the following solvent systems: chloroform : methanol : acetic acid $(85: 15: 5)$ for total lipids; chloroform : methanol : water $(65: 35: 8)$ for phospholipids; chloroform : methanol : water $(65$ $: 25: 4$ ) for glycolipids and petroleum ether : diethyl ether : acetic acid $(90: 10: 1)$ for neutral lipids (Stahl, 1969).

Lipids were detected with the following spray reagents: total lipids $-0.025 \%$ rhodamine $\mathrm{B} /$ ethanol - fluorescent pink spots; phospholipids-ammonium molybdate/mercury/ $\mathrm{H}_{2} \mathrm{SO}_{4}$ reagent-blue spots; glycolipids - $0.5 \%$ orcinol $/ \mathrm{H}_{2} \mathrm{SO}_{4}$-brown spots and on exposure to iodine vapor, neutral lipids appear as yellow-brown spots.

\section{Carbohydrates}

Carbohydrate component of the lipids were confirmed by UV-Vis and TLC spectral analysis as follows:

UV-Vis spectra:

$1 \mathrm{~mL}$ of sample was mixed with $4.5 \mathrm{~mL}$ of diluted $\mathrm{H}_{2} \mathrm{SO}_{4}$ and boiled for $10 \mathrm{~min}$ as method described by Chandrasekharan and BeMiller, (1980). After cooling, $0.1 \mathrm{~mL}$ of thioglycolic acid was added and the sample was kept in dark for $3 \mathrm{~h}$. The samples were then scanned 
for spectra between 350 to $450 \mathrm{~nm}$ for determination of deoxyhexose and hexose sugars.

\section{TLC analysis}

The sugars were detected by spotting the sample on silica gel 60 ( $\mathrm{F}_{254}$ Merck, Germany) and developing the plates in ethyl acetate : isopropanol (65:35) (Stahl, 1969). The plates were sprayed with anisaldehyde sulfuric acid reagent to observe for the development of colored spots (Lisboa, 1964). The sugar was identified by comparing the $\mathrm{R}_{\mathrm{f}}$ value with the standard sugar. The sugar was further confirmed by cochromatography.

Fourier transform infra-red (IR) spectroscopy (FTIR)

For characterization, dried $\mathrm{BS}$ were ground with $\mathrm{KBr}$ and pressed to obtain pellets. Infra-red absorption spectra were recorded on a FT-IR in the $4000-4001 / \mathrm{cm}$ range (Nicolet IR200 FT-IR Spectrometer). KBr pellet was used as the background reference.

\section{Quantification of BS by Orcinol assay}

The acidified culture supernatant $(5 \mathrm{~mL})$ was extracted twice with diethyl ether as described by Chandrasekharan and BeMiller, (1980). Fractions were pooled, dried and resuspended in $1 \mathrm{~mL}$ of distilled water. In $400 \mu \mathrm{L}$ of sample, $3.6 \mathrm{~mL}$ orcinol solution and boiled for $20 \mathrm{~min}$. After cooling for $15 \mathrm{~min}$ at room temperature, the absorbance was measured at $421 \mathrm{~nm}$. BS production was extrapolated from standard curve prepared with rhamnose and expressed as rhamnose equivalent (RE) $(\mathrm{mg} / \mathrm{mL})$.

\section{Cell-surface hydrophobicity}

Cells surface hydrophobicity was measured as method described by Rosenberg et al. (1980). Cells were inoculated in mineral salt medium containing $5 \mathrm{~g} / \mathrm{L}$ of crude oil as the sole carbon source and incubated at $25^{\circ} \mathrm{C}$ on a rotary shaker at $150 \mathrm{rpm}$. Cells were harvested by centrifugation at 10,000 rpm for $15 \mathrm{~min}$ and washed twice with Phosphate Urea Magnesium (PUM) buffer $\left(\mathrm{K}_{2} \mathrm{HPO}_{4}, 16.9 \mathrm{~g} ; \mathrm{KH}_{2} \mathrm{PO}_{4}, 7.3 \mathrm{~g}\right.$; Urea, $18.0 \mathrm{~g}$, $\mathrm{MgSO}_{4} \cdot 7 \mathrm{H}_{2} \mathrm{O}, 0.2 \mathrm{~g}$; Distilled water, $1 \mathrm{~L} ; \mathrm{pH} 7.0$ ) and resuspended in same buffer to obtain absorbance of 1.0 at $400 \mathrm{~nm} .0 .3 \mathrm{~mL}$ of $\mathrm{n}$-hexadecane was added and solution was vortexed for $30 \mathrm{sec}$ and allowed to stand for $30 \mathrm{~min}$ at room temperature for separation of lower aqueous and upper organic phase. The aqueous phase was removed with a pasteur pipette. The absorbance of aqueous phase was measured at $400 \mathrm{~nm}$ and percentage adherence to $n$-hexadecane was calculated as:

$\%$ Hydrophobicity $=\left(1-\mathrm{A}_{400}\right.$ of aqueous phase $/$ $\mathrm{A}_{400}$ of cell suspension) $\times 100$

\section{Emulsification activity}

Cells were inoculated in mineral salt medium supplemented with $5 \mathrm{~g} / \mathrm{L}$ of crude oil and incubated at their optimum temperature for 7 days on rotary shaker at $150 \mathrm{rpm}$. Emulsification activity was measured as emulsification index - $\mathrm{E}_{24}$ (Cooper and Goldenberg, 1987). In $4 \mathrm{~mL}$ of culture supernatant (after extraction of residual oil), $6 \mathrm{~mL}$ of kerosene was added and mixed vigorously for $2 \mathrm{~min}$. This was allowed to stand for $24 \mathrm{~h}$. After $24 \mathrm{~h}$, emulsification activity was measured as:

$\mathrm{E}_{24}(\%)=($ Height of emulsion $/$ total height $) \times 100$

\section{Growth and degradation}

Temporal effects of biosurfactant production, cellsurface hydrophobicity and emulsification activity on growth and degradation rates were examined from $4^{\text {th }}$ day onwards at 6 days intervals up to 40 days to observe the correlation with growth and degradation. Growth was measured in terms of whole cell protein and degradation rates were measured as residual crude oil (Vyas and Dave, 2007, 2010).

\section{Extraction and estimation of crude oil}

For estimation of oil degradation rates by gravimetric and spectrofluorometric analyses, oil was extracted with $5 \mathrm{~mL}$ of $\mathrm{n}$-hexane (HPLC grade). Extraction was carried out twice to ensure complete recovery of oil. The volume of extracted oil was deducted from the previously weighed beaker. For spectrofluorometric analysis, the dried extract was transferred to a volumetric flask and the volume was made up to $10 \mathrm{~mL}$ with n-hexane. Fluorescence was measured using Perkin Elmer (LS 50) Luminescent spectrophotometer. Calibration curves were constructed using oil dissolved in n-hexane in concentrations ranging from 1-20 $\mu \mathrm{g} / \mathrm{L}$. Synchronous excitation/emission spectra were taken of each sample. Crude oil gave maximum fluorescence at $310 \mathrm{~nm}$ and at excitation $360 \mathrm{~nm}$ emission wavelengths. Oil degradation rates were calculated by multiplying the emission spectra with the $\mathrm{F}$ factor calculated with various concentrations of crude oil (Grassoffet al., 1976). 


\section{Statistical analyses}

Data were analyzed for Pearson correlation coefficient for all the three parameter i.e., biosurfactant production, cell-surface hydrophobicity and emulsification activity with growth and degradation using SPSS 14.0

\section{RESULTS AND DISCUSSION}

Crude oil degrading marine bacteria $N$. otitidiscaviarum MTCC 6471 was examined for the production of biosurfactant by blue agar and blood agar plate assays. The organisms formed halos on blue agar plates, which detected the production of extracellular surfactant (Siegmund and Wagner, 1991). Moreover, the isolate showed $\alpha$-hemolysis on blood agar plates after $48-72 \mathrm{~h}$ of incubation indicating partial lyses of the blood due to formation of black color on agar plate (Fig. 1). The partially purified product was examined for their chemical nature. The biosurfactant produced by the isolate was found to be lipid as they produced fluorescent pink colored spots on TLC on spraying with rhodamine B reagent. Determination of the type of lipid i.e, phospholipids, glycolipids and neutral lipids revealed the surfactant to be glycolipid as they produced brown spots on spraying with $0.5 \%$ orcinol in $\mathrm{H}_{2} \mathrm{SO}_{4}$. $N$. otitidiscaviarum MTCC 6471 showed $R_{f}$ value 0.72 which is almost identical to the authentic glycolipids (Cho et al., 1998).
Phospholipids and neutral lipids could not be detected. BS of glycolipid type is generally known to have hexose as a sugar component. One exception is rhamnolipid, which has deoxyhexose as the hydrophilic structure in glycolipid. UV-Vis spectral analysis had been used to identify the hexose or deoxyhexose component of glycolipid. Fig. 2a shows the spectra of hexose (glucose) with a shoulder at $440 \mathrm{~nm}$ and Fig. 2b shows the spectra of surfactant with no shoulder at $440 \mathrm{~nm}$, confirming the presence of deoxyhexose (rhamnose). Detection of type of sugar by TLC analysis, revealed the presence of rhamnose as it developed green colored spots on spraying with anisaldehyde $\mathrm{H}_{2} \mathrm{SO}_{4}$ reagent with $\mathrm{R}_{\mathrm{f}}$ value 0.62 identical to standard rhamnose sugar $\left(\mathrm{R}_{\mathrm{f}}=0.63\right)(\mathrm{Stahl}, 1969)$. The identification of rhamnose was further confirmed by co-chromatography. Thus, by both TLC and UVVis spectral analyses, the biosurfactants produced by the isolates was characterized as rhamnolipid. These findings support the fact that rhamnolipids possess hemolytic properties (Johnson and Boese-Marrazzo, 1980). Fig. 3 shows the typical FTIR spectra of BS for the band region 4000-400 $1 / \mathrm{cm}$. The absorption bands include 3588 and $3423 \mathrm{1} / \mathrm{cm} \mathrm{O-H} \mathrm{stretching,} 2923$ and $28531 / \mathrm{cm} \mathrm{C}-\mathrm{H}$ stretching band of $\mathrm{CH}_{2}$ and $\mathrm{CH}_{3}$. The deformation vibrations at $14541 / \mathrm{cm}$ also confirm the presence of alkyl group. Carbonyl group stretching was found at $17171 / \mathrm{cm}$ which is characteristic for ester

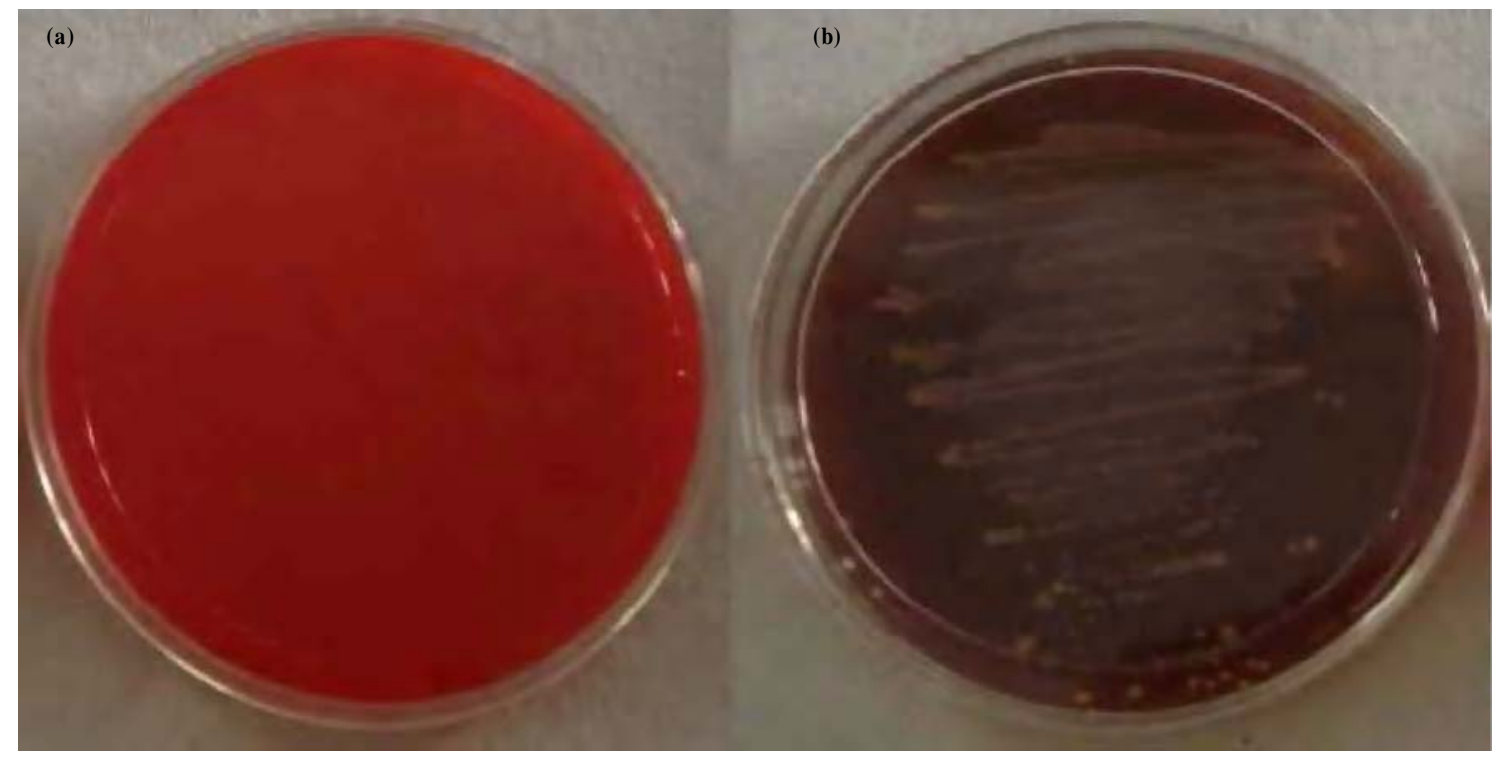

Fig. 1: (a) control plate (b) $\alpha$-hemolysis after 72 hours by $N$. otitidiscaviarum MTCC 6471 
Int. J. Environ. Sci. Tech., 8 (2), 425-432, Spring 2011
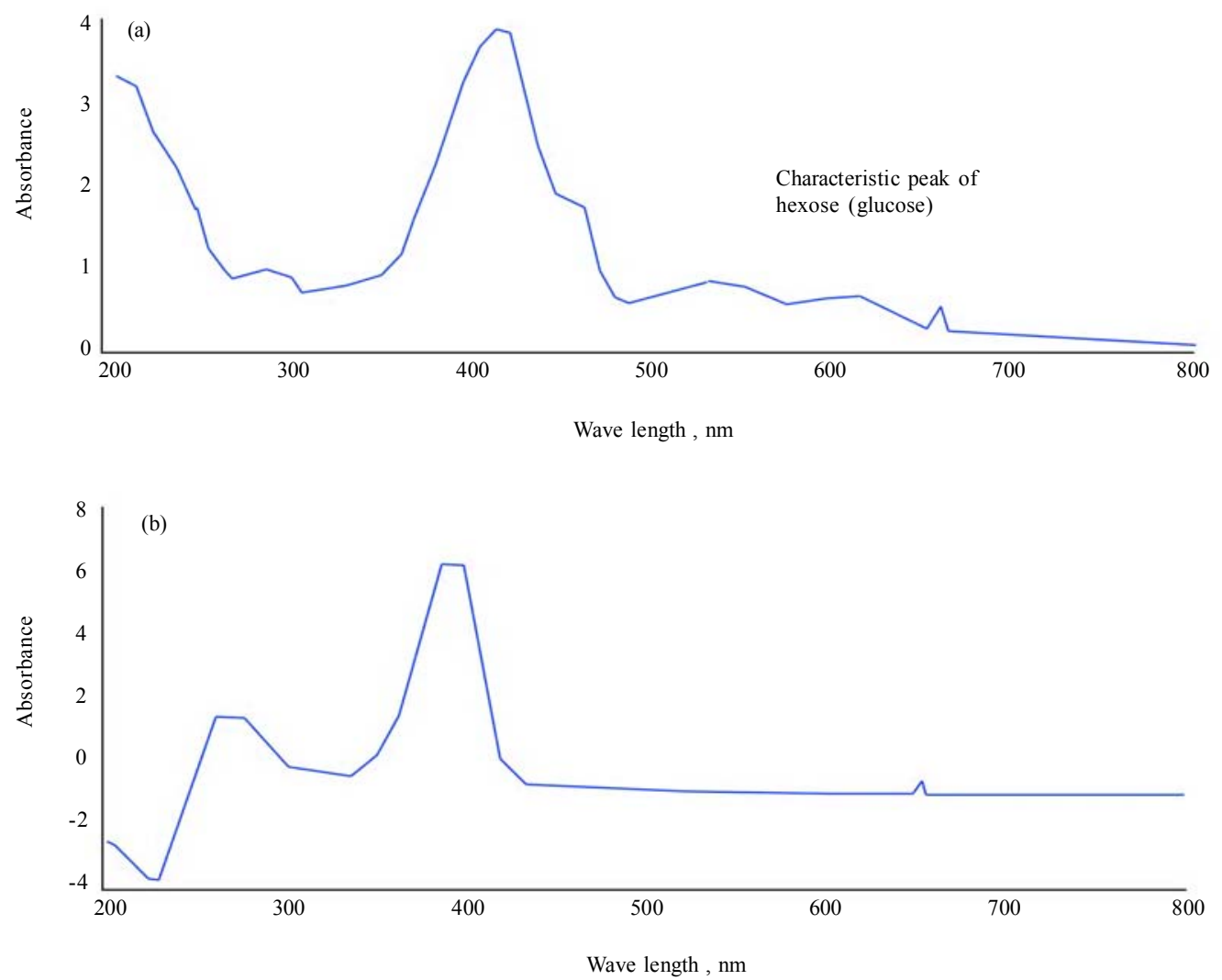

Fig. 2: UV-vis spectra of BS a) spectra of hexose with shoulder at $440 \mathrm{~nm} \mathrm{~b}$ ) spectra of BS by $N$. otitidiscaviarum MTCC 6471 without shoulder at 440

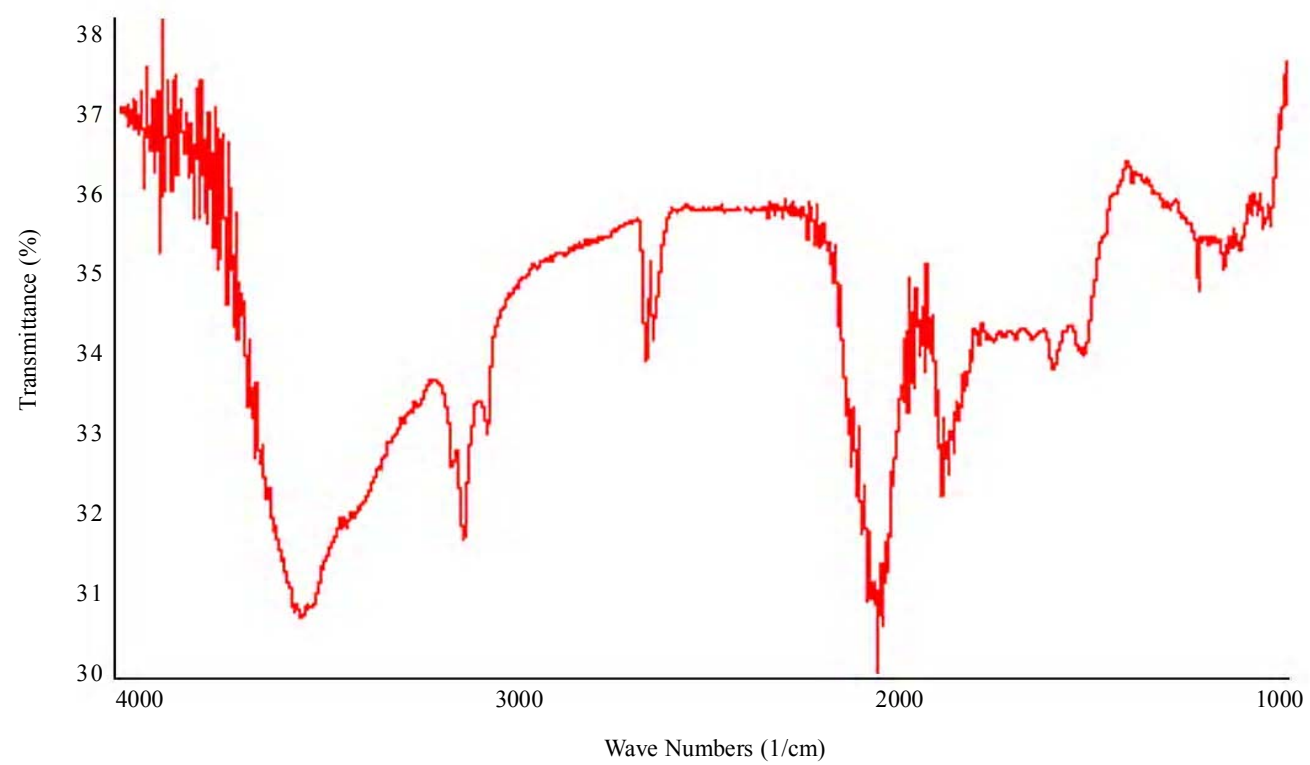

Fig. 3: FTIR spectra of BS of N. otitidiscaviarum 
compound. The ester carbonyl was also proved from the band at $11161 / \mathrm{cm}$. Thus, TLC, UV-Vis spectral and FTIR analyses of the biosurfactant produced by the isolate was characterized as rhamnolipid and quantified as rhamnose equivalent ( $\mathrm{RE} \mathrm{mg} / \mathrm{mL}$ ).

Cells-surface hydrophobicity increased with increase in biosurfactant production. Maximum hydrophobicity $(83 \%)$ was attained on the day of maximum biosurfactant production i.e. on $28^{\text {th }}$ day (Fig. 4). Cells also lost cell-surface hydrophobicity with decrease in biosurfactant production, indicating its significant positive correlation $(\mathrm{p} \leq 0.01, \mathrm{p}=0.00923)$. The involvement of surfactant in hydrocarbon assimilation/ uptake was monitored by correlating biosurfactant production as a function of emulsification activity. Results indicated that both biosurfactant production and emulsification activity increased, from early log phase and reaching its maximum at the late log phase and declining thereafter. Maximum emulsification activity $(75 \%)$ was observed on the day of maximum biosurfactant production i.e, on $28^{\text {th }}$ day of incubation.

The results indicate positive correlation between growth, degradation and biosurfactant production. Growth, degradation and surfactant production were initiated from lag phase, reaching its peak at late log phase and declining thereafter. Maximum growth $(0.61$ $\mathrm{mg} / \mathrm{mL})$ and degradation as $(19.3 \%)$ were observed on the day of maximum biosurfactant production $(0.4 \mathrm{mg} /$ $\mathrm{mL}$ ). Increase in degradation rates may be due to the fact that biosurfactant increases the solubilization of oil leading to increase in its surface area thus, increasing the degradation rates. The present results are in accordance to the above observations

Statistical analysis using Pearson bivariat method indicates that biosurfactant production, cells-surface hydrophobicity and emulsification activity correlated significantly with growth $(\mathrm{p}=0.000984,0.009309$, 0.009621 respectively) at 0.001 to $0.01 \%$ and with degradation rates $(\mathrm{p}=0.009172,0.0433002,0.009661$ respecitvely) at $0.01 \%$ except cells-surface hydrophobicity with degradation at $0.05 \%$ level as analyzed by SPSS 14. Biosurfactant production, cellssurface hydrophobicity and emulsification activity correlated to each other at $0.01 \%$.

Detection of rhamnolipid biosurfactants produced by $N$. otitidiscaviarum MTCC 6471 is in accordance to most of the studies on Pseudomonas, which produces rhamnolipid biosurfactant (Fiechter, 1992; Desai et al., 1994) a unique observation as Nocardia is known to produce trehalose biosurfactant. It has been reported that dispersion of hydrophobic substrate could be increased $10^{3}$ fold by the addition of rhamnolipid. The

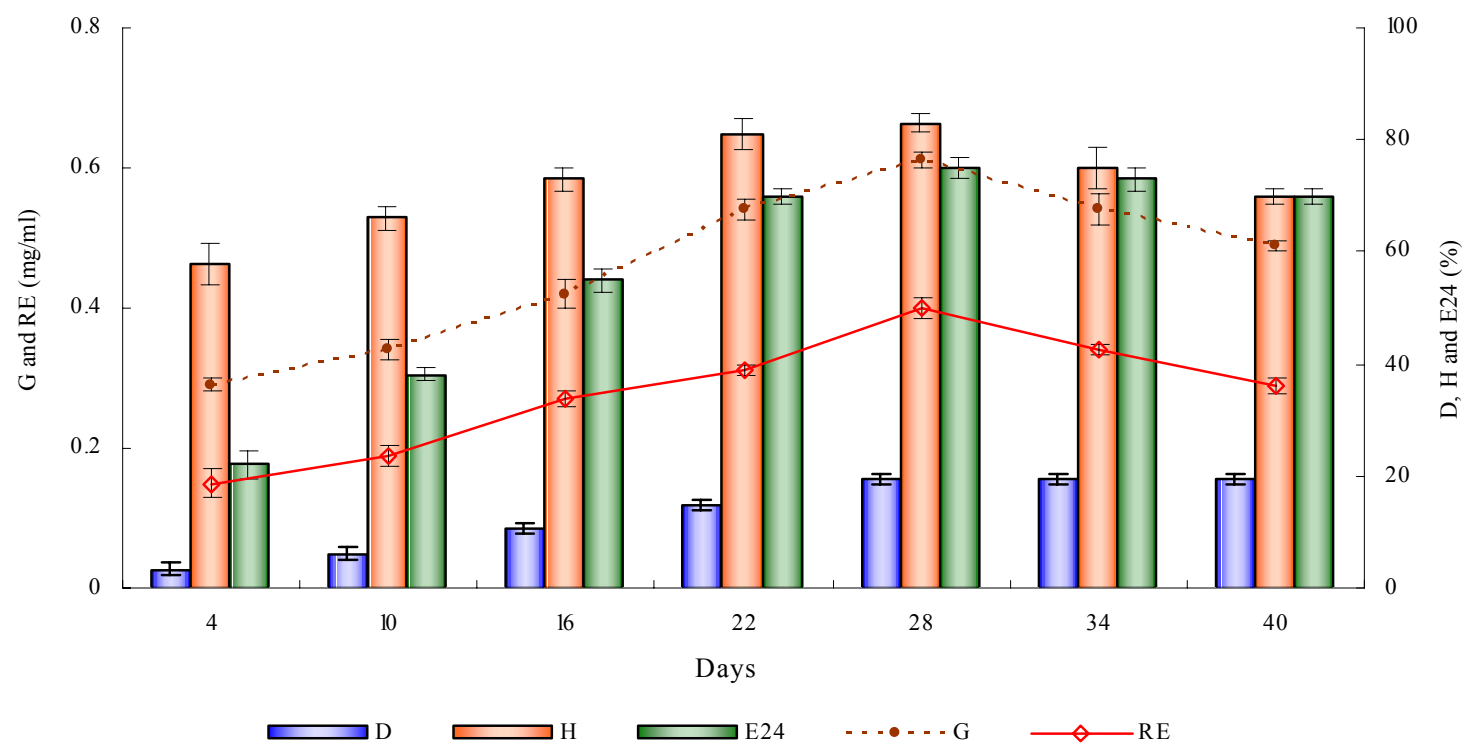

Fig. 4: Temporal effect of biosurfactant production, cell-surface hydrophobicity, emulsification activity on growht and degradation by $N$. otitidiscaviarum (error bar indicats SD) (D = Degradation, $\mathrm{E}=$ emulsification acitivity, $\mathrm{G}=$ growth, $\mathrm{H}=$ Hydrophobicity, $\mathrm{RE}=$ rehmnose equivalent) 
results of the present study also imply that crude oil degradation rates are dependent on both emulsification activity and the cell-surface properties. Thus, higher degradation activity can be attributed to higher emulsification activity by the rhamnolipid biosurfactants which can be explained by increase in the amount of available hydrocarbons due to the solubilizing effect of biosurfactants.

The results suggest that biosurfactant production, cell surface hydrophobicity and emulsification activity of the isolate was growth associated. The emulsification activity in the medium increased with growth and reached its maximum at late log phase to early stationary phase, suggesting that production of biosurfactant is growth-associated. As emulsification activity is correlated to degradation at highly significant level, it can be conclude that it plays a role in hydrocarbon uptake. Bredholt et al. (2002) have reported that cells develop a strong hydrophobic character during exponential phase $(100 \%)$, which was lost when cells entered stationary phase which supports our finding. Emulsification reduces the size of oil droplets to less than $1 \mu \mathrm{m}$, increasing the interfacial area. Our results strongly suggest that greater the interfacial area, greater the growth rate and cell-surface hydrophobicity and hence, higher emulsification activity. Based on the results obtained, it can be proposed that biosurfactant produced by the isolates pseudo-solubilize crude oil in the medium. The cells up take this pseudo-solubilized crude oil via interaction with hydrophobic cell surface. The increased cell surface hydrophobicity will also facilitate the direct contact between cells and the crude oil droplets. These two mechanisms will help the organisms to grow even at high concentrations of crude oil. The present results i.e., growth-associated production of extracellular biosurfactant and increase in cell surface hydrophobicity during growth, pseudosolubilizing crude oil allows direct contact with crude oil particles support our observations of efficient crude oil degradation.

\section{CONCLUSION}

There are a number of reports on production on rhamnolipid production by Pseudomonas spp. As per the present study, Nocardia otitidiscaviarum is also a producer of rhamnolipid biosurfactants, an observation in contrast to earlier reports on the production of trehalose biosurfactants by the isolate. When cells are grown on hydrophobic compounds, they change their cell-surface hydrophobicity and make them more compatible for uptake of hydrophobic compounds. By coordination of both the mechanism i.e., production of extra cellular surfactant and changing in surface hydrophobicity make this organisms cosmopolitan for crude oil degradation. $N$. otitidiscaviarum, a marine isolate has not yet been reported to produce rhamnolipid biosurfactants, can be a potential candidate for the restoration of oil contaminated marine environment.

\section{ACKNOWLEDGEMENTS}

The authors thank Ministry of Earth Sciences (MoES), Government of India, New Delhi, for the financial assistance (DOD/12-MMDP/4/01/(P-2)).

\section{REFERENCES}

Adams, R. H.; Guzman-Osorio, F. J.; Zavala Cruz, J., (2008). Water repellency in oil contaminated sandy and clayey soils. Int. J. Environ. Sci. Tech., 5 (4), 445-454 (10 pages).

Alexander, M., (1999). Biodegradation and Bioremediation. $2^{\text {nd }}$ Ed. Academic Press, San Diego.

Al-Tahhan, A.; Sandrin, T. R.; Bodour, A. A.; Maier, R., (2000). Rhamnolipid-induced removal of lipopolysac-charide from Pseudomonas aeruginosa: effect on cell surface properties and interaction with hydrophobic substrates., Appl. Environ. Microbiol., 66, 3262-3268 (7 pages).

Atlas, R. M.; Bartha, R., (1992). Hydrocarbon biodegradation and oil spill bioremediation, in: Marshall, K. C., (Ed), Advances in Microbial Ecology. Plenum Press, New York, 287-338 (52 pages).

Banat, I. M., (1993). The isolation of thermophilic biosurfactant producing Bacillus species. Biotech. Letter, 15, 591-594 (4 pages).

Beal, R.; Betts, W. B., (2000). Role of rhamnolipid biosurfactants in the uptake and mineralization of hexadecane in Pseudomonas aeruginosa. J. Appl. Microbiol., 89, 158-168 (11 pages).

Bonin, P.; Ranaivoson, E. R.; Raymond, N.; Chalamet, A.; Bertrand, J. C., (1994). Evidence for denitrification in marine sediment highly contaminated by petroleum products. Marine Poll. Bull., 28, 89-95 (7 pages).

Bredholt, H.; Bruheim, P.; Potocky, M.; Eimhjellen, K., (2002). Hydrophobicity development, alkane oxidation and crude oil emulsification in Rhodococcus species. Can. J. Microbiol., 48, 295-304 (10 pages).

Chandrasekharan, E. V.; BeMiller, J. N., (1980). Constituent analysis of glycosaminoglycans. in: Whistler, R. L., (Ed), Methods in Carbohydrates Chemistry. Academic Press, NY, USA, 8, 95-96 (2 pages).

Cho, J-H.; Jeong, Y-L.; Park, O-J.; Yoon, B-D.; Yang, J. W., (1998). Characterization of glycolipid biosurfactants from an isolated strain of Pseudomonas aeruginosa YPJ 80. J. Microbiol. Biotech., 86 (6), 645-649 (5 pages).

Cooper, D. G.; Goldenberg, B. G., (1987). Surface-active agents from two Bacillus species. Appl. Environ. Microbiol., 53, 224-229 (6 pages). 
Desai, A. J.; Patel, R.; Desai, J. D., (1994). Advances in production of biosurfactants and their commercial applications. J. Sci. Indus. Res., 53, 619-629 (11 pages).

Fiechter, A., (1992). Biosurfactants: moving towards industrial application. Trends in Biotech., 10, 208-217 (10 pages).

Francy, D. S.; Thomas, J. M.; Raymond, R. L.; Ward, C. H., (1991). Emulsification of hydrocarbons by subsurface bacteria. J. Indus. Microbiol., 8, 237-246 (10 pages).

Goyal, P.; Sharma, P.; Srivastava, S.; Srivastava, M. M., (2008). Saraca indica leaf powder for decontamination of $\mathrm{Pb}$ : Removal, recovery, adsorbent characterization and equilibrium modeling. Int. J. Environ. Sci. Tech. 5 (1), $27-$ 34 (8 pages).

Grassoff, K.; Kermling, K.; Ehrhardt, M., (1976). Methods of Seawater Analysis, Verlag Chemie, Weinbein.

Haghighat, S.; Akhavan Sepahy, A.; Mazaheri Assadi, M.; Pasdar, H., (2008), Ability of indigenous Bacillus licheniformis and Bacillus subtilis in microbial enhanced oil recovery, Int. J. Environ. Sci. Tech., 5, 385-390 (6 pages).

Husseien, M.; Amer, A. A.; El-Maghraby, A.; Taha, N. A., (2009).Availability of barley straw application on oil spill clean up. Int. J. Environ. Sci. Tech., 6 (1), 123-130 (8 pages).

Johnson, M. K.; Boese-Marrazzo, D., (1980). Production and properties of heat-stable extracellular hemolysin from Pseudomonas aeruginosa. Infect Immun., 29 (3), 1028 1033 (6 pages).

Juang, D. F. ; Yuan, C. S. ; Hsueh, S. C.; Chiou, L. J., (2009a). Distribution of volatile organic compounds around a polluted river. Int. J. Environ. Sci. Tech., 6 (1), 91-104 (14 pages).

Juang, D. F. Lee, C. H. ; Hsueh, S. C., (2009b). Chlorinated volatile organic compounds found near the water surface of heavily polluted rivers. Int. J. Environ. Sci. Tech., 6 (4), 545-556 (12 pages).

Kosamu, I. B. M.; Obst, M., (2009). The influence of picocyanobacterial photosynthesis on calcite precipitation. Int. J. Environ. Sci. Tech., 6 (4), 557-562 (6 pages).

Lisboa, B. P., (1964). Characterization of $\Delta^{4}-3-\mathrm{OXO}-\mathrm{C}_{21}{ }^{-}$ steroids on thin-layer chromatograms by "in situ" colour reactions. J. Chromat., 16, 136 - 151 (15 pages).
Nagheeby, M.; Kolahdoozan, M., (2010). Numerical modeling of two-phase fluid flow and oil slick transport in estuarine water. Int. J. Environ. Sci. Tech., 7 (4), $771-784$ (8 pages).

Oberbremer, A.; Muller-Hurtig, R.; Wagner, F., (1990). Effect of the addition of microbial surfactants on hydrocarbon degradation in soil population in a stirred reactor. Appl. Microbiol. Biotech., 32, 485-489 (5 pages).

Panagoda, G. J.; Ellepola, A. N.; Samaranayake, L. P., (2001). Adhesion of Candida parapsilosis to epithelial and acrylic surfaces correlates with cell surface hydrophobicity. Mycoses, 44, 29-35 (7 pages).

Prabhu, Y.; Phale, P. S., (2003) Biodegradation of phenanthrene by Pseudomonas sp. strain PP2: novel metabolic pathway, role of biosurfactant and cell surface hydrophobicity in hydrocarbon assimilation, Appl. Microbiol. Biotech., 61, 342-351 (10 pages).

Rosenberg, M.; Gutnick, D. L.; Rosenberg, E., (1980). Adherence of bacteria to hydrocarbons: a simple method for measuring cell-surface hydrophobicity. FEMS Microbiol. Letters, 9, 29-33 (5 pages).

Siegmund, I.; Wagner, F., (1991). New method for detecting rhamnolipids excreted by Pseudomonas species during growth on mineral agar. Biotech. Tech., 5, 265-268 (4 pages).

Singleton, D. R.; Furlong M. A.; Rathbun, S. L.; Whitman, W. B., (2001). Quantitative comparisons of $16 \mathrm{~S}$ rRNA gene sequence libraries from environmental samples. Appl. Environ. Microbiol., 67, 4374-4376 (3 pages).

Stahl, E., (1969). Thin-Layer Chromatography. Springer Verlag, New York.

Vyas, T. K.; Dave, B. P., (2007). Effect of crude oil concentrations, temperature and $\mathrm{pH}$ on growth and degradation of crude oil by marine bacteria. Indian J. Marine Sci., 36 (1), 76-85 (10 pages).

Vyas, T. K.; Dave, B. P., (2010). Effect of addition of nitrogen, phosphorus and potassium fertilizers on biodegradation of crude oil by marine bacteria. Indian $\mathrm{J}$. Marine Sci., 39 (1), 143-150 (8 pages).

Zhang, Y.; Miller, R. M., (1992). Enhanced octadecane dispersion and biodegradation by a Pseudomonas rhamnolipid surfactant (biosurfactant). Appl. Environ. Microbiol., 58, 3276-3282 (7 pages).

Zobell, C. E., (1946). Action of microorganisms on hydrocarbons. Bacteriol. Rev., 10, 1-49 (49 pages).

AUTHOR (S) BIOSKETCHES

Vyas, T. K., Ph.D., Assistant Professor, P D Patel Institute of Applied Sciences, Charotar University of Science and Technology, Changa, Gujarat, India. Email: vyastrupti@hotmail.com

Dave, B. P., Ph.D., Professor, Department of Life Sciences, Bhavnagar University, Bhavnagar, Gujarat, India. Email: bpd8256@gmail.com

How to cite this article: (Harvard style)

Vyas, T. K.; Dave, B. P., (2011). Production of biosurfactant by Nocardia otitidiscaviarum and its role in biodegradation of crude oil. Int. J. Environ. Sci. Tech., 8 (2), 425-432. 